\title{
Mapeamento geomorfológico da Serra do Espinhaço Meridional:
}

\section{primeira aproximação}

\author{
Cristina Helena Ribeiro Rocha Augustin ${ }^{1}$, Bráulio Magalhães Fonseca ${ }^{2}$, Leonardo Cristian Rocha ${ }^{3}$ \\ 1 - Centro de Pesquisa Manoel Teixeira da Costa e Departamento de Geografia, Universidade Federal de Minas Gerais, Av. Antônio Carlos 6627, \\ Pampulha. CEP: 31270-901. Belo Horizonte, MG, Brasil. E-mail: chaugust@hotmail.com \\ 2 - Departamento de Cartografia, Universidade Federal de Minas Gerais-UFMG; Av. Antônio Carlos 6627, Pampulha. CEP: 31270-901. Belo Horizonte, \\ MG, Brasil. E-mail: brauliomagalhaes@gmail.com \\ 3 - Departamento de Geociências / Universidade Federal de São João Del Rey, Campus CTAN, Av. Visconde do RioPreto, S/n, Colônia do Bengo, \\ CEP: 36301360, São João Del Rey, MG, Brasil. E-mail: rochageo@hotmail.com
}

Recebido em 24 de outubro de 2011, aceito em 27 de outubro de 2011

RESUMO: O mapeamento geomorfológico em escala regional constitui um importante instrumento na espacialização dos elementos morfoestruturais do relevo. Tais mapeamentos auxiliam de maneira ágil e direta na compreensão dos elementos bio-físicos envolvidos tanto na evolução do relevo, quanto na sua caracterização. Grandes cinturões orogenéticos, como a Serra do Espinhaço, representam um laboratório ideal para testar mapeamentos de escala regional, voltados para o estudo dos aspectos morfoestruturais da paisagem. 0 presente trabalho buscou aplicar novas tecnologias de mensuração e representação cartográfica das formas de relevo da Serra do Espinhaço Meridional (SdEM). Para isto foi desenvolvida, a partir da análise de dados primários e secundários, chave interpretativa para o mapeamento.

Palavras-chave: mapeamento geomorfológico, Espinhaço Meridional, modelagem digital de elevação, análise geomorfológica, técnicas de geoprocessamento.

ABSTRACT: GEOMORPHOLOGICAL MAPPING OF ESPINHAÇO MERIDIONAL MOUNTAIN RANGE: FIRST APPROXIMATION. Geomorphologic mapping in regional scale is an important instrument for spacializing the morphoestructural elements of landform. These mappings can also become an agile and straightforward tool for enabling the understanding of bio-physical elements involved in landscape evolution as well as their characterization. Extensive orogenetic belts such as the Espinhaço constitute an ideal laboratory for testing large scale mappings linked to the studies of morphoestructural aspects of the landscape. This paper aims to apply new cartographical technologies such as GIS using them for measurements and representation of the Serra do Espinhaço Meridional (SdEM), a mountain range located in Minas Gerais State, Brazil. Taking as reference primary and secondary data it was possible to develop an interpretation Key for the geomorphologic mapping.

Keywords: geomorphologic mapping, Espinhaço Meridional, digital terrain modeling, geomorphologic analysis, geoprocessing techniques.

\section{INTRODUÇÃO}

De acordo com União Internacional de Geomorfologia (UIG) "mapas são uma das maneiras mais apropriadas e sintéticas de mostrar a distribuição das formas de relevo, os depósitos da superfície e sub-superfície, os processos que atuam na paisagem e o período de tempo dessa ação". Para isto, a geomorfologia utiliza representações cartográficas para espacializar seu objeto de estudo e assim melhor visualizar as formas e os processos, buscando elementos que auxiliem na melhor compreensão da evolução e dinâmica do relevo do relevo. Como toda a representação cartográfica, mapeamentos geomorfológicos variam em função do que se pretende representar e da escala desta representação.

É nesse sentido que apresentamos esta proposta de mapeamento das grandes compartimentações geomorfológicas do Espinhaço Meridional e do seu entorno mais imediato. Ela tem como objetivo fornecer uma primeira aproximação sobre a caracterização, fatores associados, dinâmica e distribuição espacial dos principais conjuntos de formas de relevo deste importante orógeno brasileiro. No presente mapeamento, tendo em vista a grande influência da lito-estrutura na elaboração e distribuição espacial das formas de relevo, estes fatores serviram de base para a construção dos dois primeiros táxons utilizados: estrutura geológica e litologia.

Embora mapeamentos intermediários de análise tenham sido realizados em escala de 1:100.000, estes serão apresentados na escala de 1:250.000, o que relativiza as informações a serem representadas e utilizadas para a análise do mapeamento. Essa abordagem é reconhecida por Hayden (1986), ao chamar a atenção para o fato de que os mapeamentos geomorfológicos vêm mudando, passando de uma abordagem focada em áreas ou aspectos específicos da paisagem, para aquelas voltadas para uma perspectiva da compreensão mais regional do relevo. Ele aponta que, de 2000 até hoje, é possível distinguir na literatura, de maneira geral, uma organização da representação do relevo em mapas de dois tipos principais: aqueles analíticos, com base em informações sobre gênese, morfografia, morfometria e cronologia, e outro, denominado por ele de sintéticos, constituídos pela síntese dos dados analíticos, combinados com parâmetros como solo, vegetação e hidrologia. O próprio autor reconhece ainda um terceiro tipo, que vem sendo cada vez mais utilizado na 
geomorfologia, o dos "geohazards", com base na representação de feições e processos de risco.

O atual mapeamento pode ser classificado como pertencente ao grupo de mapeamentos analíticos, pois busca representar e analisar informações sobre os aspectos morfoestruturais e morfoesculturais do relevo, que têm como base elementos da gênese, cronologia, morfometria e morfografia das formas no domínio do Espinhaço Meridional. Para isto, foram utilizadas importantes dados e informações obtidas através de mapas geológicos, na escala de 1:100.000, elaborados no âmbito do Projeto Mapeamento Geológico do Espinhaço, da CODEMIG, antiga COMIG.

No Brasil, grande parte dos mapeamentos geomorfológicos teve sua base metodológica nos trabalhos de Tricart (1965). Este foi o caso dos mapeamentos produzidos no âmbito do Projeto RADAM e os mapeamentos geomorfológicos produzidos por Ross \& Moroz (1997), para o estado de São Paulo, na escala 1:500.000, e o de Cordeiro et al. (2009), para o Paraná, e das considerações de Ross (1992) .

Segundo Tricart (1965), os mapeamentos geomorfológicos abordam quatro tipos principais de representação: a da morfometria, correspondendo à altimetria, dimensões, desníveis, extensões entre outros itens associados à mensuração das unidades do relevo; a da morfologia, agregada à forma das vertentes, vales, topos, etc.; a da gênese ligada à desnudação e/ou agradação e à cronologia (idade relativa e datação absoluta das formas), e a do comportamento morfodinâmico (Casseti, 2005; Souza, 2003, apud Rodrigues, 1998; Gustavsson et al, 2006).

Outros autores, contudo, (Cooke et al., 1974; Goudie, 1981) lembram que mapeamentos geomorfológicos variam de maneira ampla quanto ao nível de medidas, escala, tipo de informações apresentadas, e tipo de uso do mapeamento. Eles chamam a atenção para os trabalhos das subcomissões de mapeamento geomorfológico da IGU, indicando que a base temática pode variar e incluir aos fatores litológicos, também os componentes estruturais, como proposto por Demek (1972), e utilizado no presente mapeamento.

As representações cartográficas dos fenômenos que ocorrem na superfície terrestre desempenharam e continuam desempenhando um importante papel na ocupação do homem na Terra. A sistematização cartográfica do relevo constitui um importante instrumento na espacialização dos fatos geomorfológicos, no que tange a expressão dos condicionantes estruturais e climáticos que comandam o seu modelado. Portanto, nunca é demais ressaltar o papel da cartografia geomorfológica no âmbito da pesquisa em Geomorfologia, e sua importância como instrumento de análise e elaboração de cenários futuros sobre a dinâmica evolutiva da superfície da Terra.

Tendo como base o que estabelece o mesmo grupo de trabalho do International Association of Geomorphologists (IAG), ao propor que "Geomorphological maps are one of most important end products of investigations made by geomorphologists on the territory", pode-se considerar o presente mapeamento como um produto final, já que constitui o resultado da análise e interpretação da área de estudo. Mas também, como apontado por Tricart (1965), ele pode ser considerado como base de uma pesquisa, e não somente sua finalização.

Como qualquer interpretação, a atual proposta constitui um resultado dinâmico, interpretativo, que pode servir de base para outras análises e mapeamentos geomorfológicos da região. Acreditamos, assim, que este possa ser o ponto de partida para outros estudos, e que forneça uma base inicial para diferentes propostas cartográfica, ou para estudos que busquem compreender melhor a dinâmica do Espinhaço.

\section{LOCALIZAÇÃO E CARACTERIZAÇÃO DA ÁREA DE ESTUDO}

A Serra do Espinhaço Meridional (SdEM) representa um cinturão orogênico que limita o sudeste do Cráton do São Francisco, e estende-se por cerca de $300 \mathrm{~km}$ na direção $\mathrm{N}-\mathrm{S}$, desde o Quadrilátero Ferrífero (Serra do Ouro Branco) até a região de Olhos d'Água (Almeida Abreu, 1995). Para nordeste, une-se com a Faixa Araçuaí com a qual forma o grande complexo denominado Serra do Espinhaço. A porção mapeada encontra-se localizada entre as coordenadas $-18^{\circ} 43^{\prime} 23^{\prime \prime} \mathrm{S},-44^{\circ} 14^{\prime} 42^{\prime \prime} \mathrm{W}$ e $17^{\circ} 21^{\prime} 22^{\prime \prime S}$, $-43^{\circ} 10^{\prime} 25^{\prime \prime} \mathrm{W}$ (Fig. 1), na porção denominada de Serra do Espinhaço Meridional, que compreende toda a área do orógeno abaixo do paralelo $17^{\circ} \mathrm{Sul}$.

A arquitetura geológica da SdEM é caracterizada predominantemente por quartzitos distintos que, juntamente com suas características estruturais, conferem um arranjo arqueado e topograficamente elevado ao orógeno. De acordo com Saadi (1995), a SdEM é geomorfologicamente caracterizada, no estado de Minas Gerais, por um conjunto de terras altas, com forma de bumerangue de direção geral norte-sul e convexidade orientada para oeste. Este autor defende que o termo "serra" esconde a realidade fisiográfica do Espinhaço, o qual seria melhor definido pelo termo "planalto". Tal 


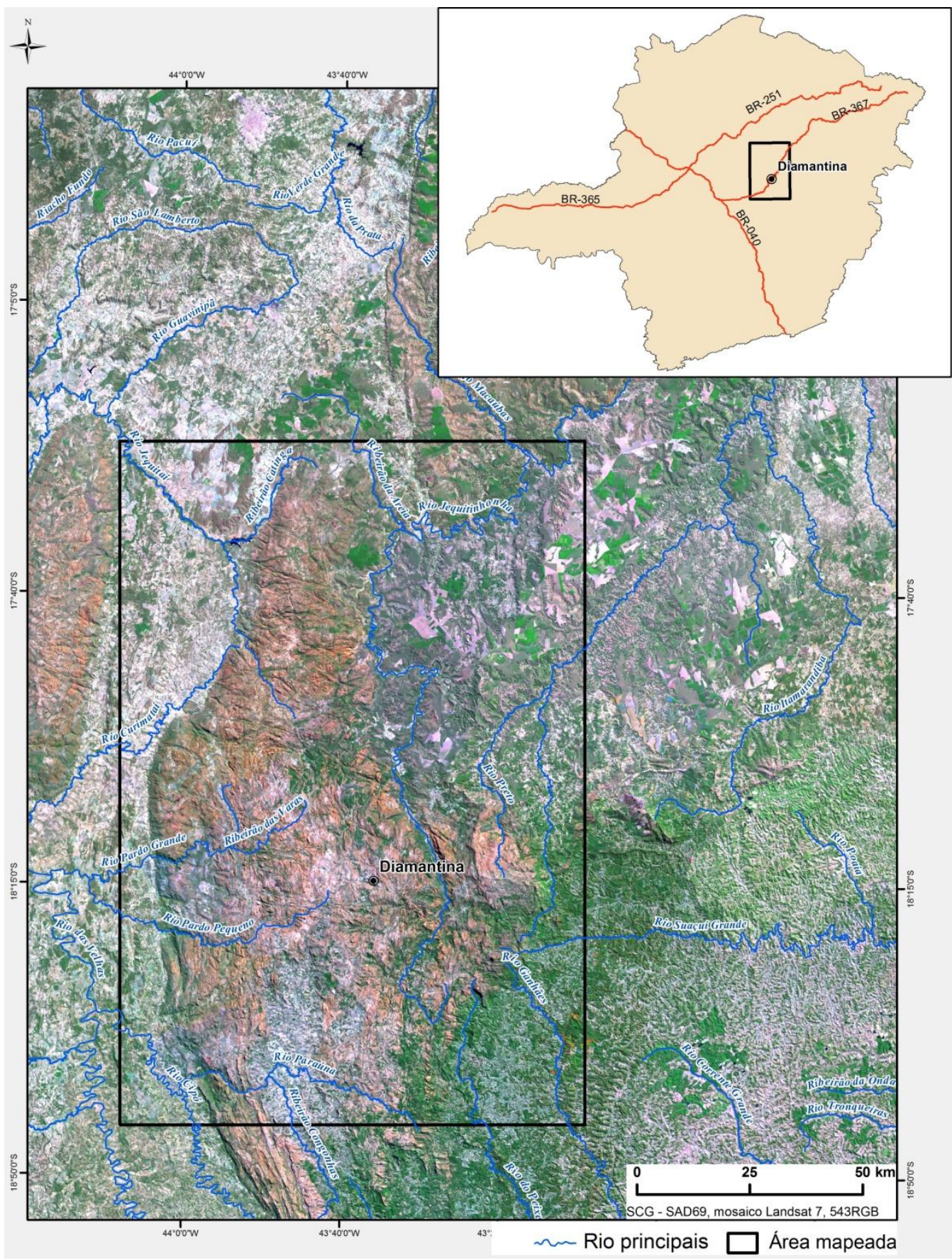

Fig. 1. Localização da área mapeada

terminologia foi utilizada também por Abreu (1982),que identificou na área níveis altimétricos correspondentes às superfícies Gondwana, PósGondwana, Sul Americana e Ciclo Velhas mapeadas em 1956 por Lester King. Níveis correspondentes foram estudados e caracterizados em Gouveia por Augustin (1995b).

Segundo dados do IBGE (1978), o clima em macro escala da SdEM pode ser classificado como de ambiente transicional entre: Mesotérmico Brando Semi-Úmido do Brasil Central e Sub-Quente SubÚmido do Brasil Central. No clima Sub-quente semiúmido, as médias térmicas anuais giram em torno de $27^{\circ} \mathrm{C}$ a $30^{\circ} \mathrm{C}$, diferentemente do Mesotérmico
Brando Semi-Úmido, que possui médias térmicas anuais mais baixas, próximas a $22^{\circ} \mathrm{C}$. A pluviosidade média anual é de $1400 \mathrm{~mm}$, concentrada nos meses mais quentes, de outubro a março.

A cobertura vegetal é caracterizada pelo predomínio, nos domínios quartzíticos, de espécies típicas de altitude e rupestre, enquanto nas porções mais baixas predomina o cerrado e, ao longo dos cursos de água matas ciliares (Augustin, 1995a).

\section{METODOLOGIA}

Todo o mapeamento foi realizado com a lógica do Sistema de Informação Geográfica, e os procedimentos realizados em ambiente SIG foram 
baseados na metodologia apresentada por Fonseca (2010). O mapeamento teve inicio com a elaboração da modelagem digital de elevação (MDE) em malha TIN (triangular irregular network), com posterior avaliação das rupturas tectônicas e lineamentos do relevo. Para tal foram utilizados cartas topográficas Cartas Topográficas digitalizadas em escala de 1:100.000 (IBGE, 1978). As análises dos dados geológicos e tectônicos da área tiveram como base os mapas do Projeto Espinhaço (COMIG, 1996) e da CPRM/CPMTC, 2011, ambos na escala de 1:100.000.

Foram elaborados perfis morfológicos em várias porções da região mapeada e análises hipsométricas através do histograma das freqüências altimétricas e sua relação com as superfícies de aplainamento. Realizou-se ainda interpretação de imagens do Sensor ETM+/Landsat 7, na qual buscou-se especificar a gênese e a disposição espacial dos elementos do relevo.

Os dados topográficos, cujas modelagens foram realizada nos softwares ArcGIS 9.1 e ENVI 4.0, foram também usados para a elaboração dos seguintes produtos: declividade (Fig. 2), orientação das vertentes (Fig. 3), hipsometria (Fig. 4), modelo e criação de perfis topográficos. Para complementar a análise geomorfológica da área investigada, foi elaborado, no programa SPRING/INPE, um mosaico de duas imagens do sensor ETM+/Landsat 7, referentes às órbitas/ponto 218/072 e 218/073 das datas 23/04/2007 e 06/08/2007 respectivamente. Deve-se ressaltar que para o mapeamento geomorfológico regional não é necessário ter imagens atuais, uma vez que a dinâmica das formas de relevo não se altera perceptivelmente em pequenas escalas. As imagens foram adquiridas previamente ortorretificadas em projeção UTM (Universal Transversa de Mercator) e datum WGS84 (World Geodetic System 1984), posteriormente convertido para South American Datum 69.

Foi realizada uma composição a falsa cor com as bandas 5, 4 e 3, (resolução espacial de 30 metros) no espaço de cores RGB. A banda pan cromática do sensor, com resolução espacial de 14,25 metros também foi utilizada para melhorar a resolução espacial da imagem final, através do processo de transformação para o espaço de cores IHS.

O mapeamento contou ainda com levantamento de campo com o objetivo de testar e corrigir as interpretações realizadas previamente no gabinete, valorizando-se itinerários previamente definidos. Os mapeamentos das bases foi realizado na escala de 1:100.000, embora a consolidação dos dados através da integração das informações de campo à carta das formas de relevo tenha sido realizada na escala de 1 : 250.000 (Figs. 6 e 7), definida como a escala de apresentação final do mapeamento.
Parte do desafio desse mapeamento foi o de estabelecer uma chave interpretativa. Esta não constitui uma tarefa simples. Como aponta Gustavsson et al. (2006), a construção de um sistema de mapeamento deve incluir uma legenda que possa ser aplicada em diferentes relevos, o que demanda vários níveis de exigências. Nesse sentido, é apresentado abaixo, detalhamento sobre a chave interpretativa usado neste trabalho.

\section{1 - Desenvolvimento da Chave de interpretação}

O presente trabalho apresenta o mapeamento geomorfológico do Espinhaço Meridional, considerando, numa primeira subdivisão, os condicionantes morfoestruturais do relevo, seguido dos elementos da litologia. Como condicionantes morfoestruturais, estão incluídos elementos tectônicos, estratigráficos, e mesmo cronológicos. O segundo táxon teve como princípio o agrupamento de formas, que têm como base comum a litolologia das rochas. Em uma terceira subdivisão, buscou-se contemplar elementos da morfoescultura, com ênfase na dinâmica, ou seja, nos agrupamentos das formas que indicam processos dominantes, no sentido apontado por Demeck (1972) e trabalhado por Ross (1997), em dois grandes conjuntos: o das formas erosivas, ou seja, de degradação e os das formas deposicionais, ou de gradação. Nessas unidades foram, então, identificadas formas específicas e típicas de cada unidade, tendo como base sua morfologia e morfometria.

Desta maneira, foi proposta uma primeira divisão taxonômica de grandes unidades que representassem feições geomorfológicas com forte relação com a geologia, como os elementos tectônicos, os grandes arranjos estruturais e, em um segundo táxon, as variações litológicas. Tais fatores geram arranjos regionais do relevo com formas variadas, mas que guardam relações causais entre si. A chave de interpretação partiu da representação dos grandes elementos, que possuíssem uma representatividade zonal, para aqueles que são melhor espacializados na forma linear e/ou pontual. Foram identificadas quatro domínios e sete subdomínios morfoestruturais (Fig. 5), representadas por algarismos romanos e algarismos romanos acompanhados de arábicos. O terceiro táxon é a representação da dimensão morfescultural (Fig. 6a), tendo sido agrupado em dois níveis principais: a) Feições Predominantemente Erosivas; b) Feições Predominantemente Deposicionais.

Para hierarquizar as feições geomorfológicas a serem interpretadas e mapeadas, foram categorizadas as feições $\left(4^{\circ}\right.$ táxon) mais representativas, capazes de agrupar as feições menores: Superfícies Erosivas Remanescentes, 
Superfícies Retrabalhadas, Áreas Deprimidas e as Áreas de Influência Fluvial Imediata (Fig. 6b). Em cada uma delas encontra-se representado, em cores, o 5 o táxon que corresponde às 19 subunidades de feições dominantes em cada subdivisão do 4으 táxon (Fig. 7).

Vários mapeamentos intermediários foram realizados na escala de 1:100.000. Contudo, os resultados finais foram sintetizados na escala de 1:250.000. Em função da escala e do tipo de mapeamento proposto, buscou-se oferecer o máximo de informações possíveis sobre as unidades mapeadas, com o mínimo de subjetividade na apresentação das mesmas, como é recomendado nesse tipo de análise.

Da mesma maneira, foram levadas em consideração, as orientações propostas por Verstappen (1970, apud Gustavson et al., 2006), de construir um sistema simples, flexível, com opções de simbologia e legenda compatíveis com a escala de apresentação final do mapa, evitando, assim, uma sobrecarga de informações e dificuldade de leitura e interpretação do mapa. Também foram produzidos mapas, ou camadas de informações complementares, de maneira a facilitar a interpretação do mapa síntese, final, mapas estes analisados no texto.

De acordo com definição da IGU, o mapeamento geomorfológico síntese do Espinhaço Meridional (Fig. 7) pode ser considerado como de escala média, ou seja, aquelas entre 1:100.000 e 1:1.000.000. Ele conta com cinco táxons, dos quais os dois primeiros representam fatores estritamente geológicos, tendo em vista a importância desses elementos para a evolução, morfodinâmica e caracterização do relevo área.

Ao longo da análise os resultados, os termos maciço, orógeno, serra e domínio serão utilizados para referências com relação ao Espinhaço Meridional, sem que tenham, contudo, conotações, com exceção do último, específicas ou especiais do ponto de vista do atual mapeamento.

\section{RESULTADOS E DISCUSSÃO}

As interpretações, análises e mapeamentos preliminares possibilitaram a estruturação e organização final da chave de interpretação, e serviram de base para o mapeamento geomorfológico síntese (Fig. 7). Foram produzidos sete mapas: dos domínios morfoestruturais (Fig. 2), de hipsometria (Fig. 3), de classes de declividade (Fig. 4), de orientação do relevo (Fig. 5), dos domínios morfoesculturais ou da morfodinâmica (Fig. 6b) que auxiliados por cortes topográficos, serviram de base para a análise final apresentadas nos mapas da figura 7 .

Tendo em vista a importância dos dados fornecidos pela subdivisão da área em Morfoestruturas, este será o primeiro mapa a ser analisado.

4.1 - Domínios Morfoestruturais e Esculturais da Serra do Espinhaço Meridional e do seu entorno

A chave de interpretação começou a ser esboçada a partir da análise e interpretação do material cartográfico existente. 0 primeiro agrupamento foi o dos Domínios Morfoestruturais, como apresentados a seguir. Foram identificados quatro Domínios, com base em elementos tectônico e cronológicos, e sete Subdomínios, tendo como referência a litologia das rochas de cada Domínio (Fig. 2):

Domínio do Cráton do São Francisco, subdividido em: II1. Subdomínio das Rochas Metapelíticas e Carbonáticas do Grupo Bambuí;

Domínio do Cinturão Orogênico do Espinhaço, subdividido em: II. 1. Subdomínio das Rochas Granito-gnaíssicas do Embasamento Cristalino Remobilizado; II.2. Subdomínio das Rochas Predominantemente Quartzíticas do Supergrupo Espinhaço;

Domínio do Macaúbas, subdividido em: III. Subdomínio das Rochas Metassedimentares; III.2. Subdomínio dos Materiais Detríticos.

Domínio do Embasamento Cristalino, subdividido em: IV.1. Rochas Granito-gnáissicas do Complexo Guanhães; IV.2. Rochas Intrusivas do Complexo (SUÍTE) Borrachudo e do Grupo Itabira.

Essa compartimentação permitiu que, em um primeiro momento, fosse possível a identificação de uma moldura espacialmente mais abrangente, na qual as feições mofoesculturais pudessem ser interpretadas uma vez que a base lito-estrutural regional reflete a complexa evolução geotectônica da área mapeada (Fig. 2).

A primeira unidade individualizada no mapa da figura 2, datada do Proterozóico Inferior, é o Domínio Cratônico do São Francisco em seu contato com a borda oeste da faixa móvel do Araçuaí, dobrada no ciclo Brasiliano (600-520 Ma.), representado pelo Orógeno Espinhaço. O Domínio Cratônico nessa área é representado por rochas metapelíticas do Grupo Bambuí formadas por material de granulometria fina, argilas e siltes, intercalado por calcário, que ocorre em espessuras variadas, de lentes centimétricas a pacotes métricos (Noce \& Fogaça; Knauer \& Fogaça, 1996). 


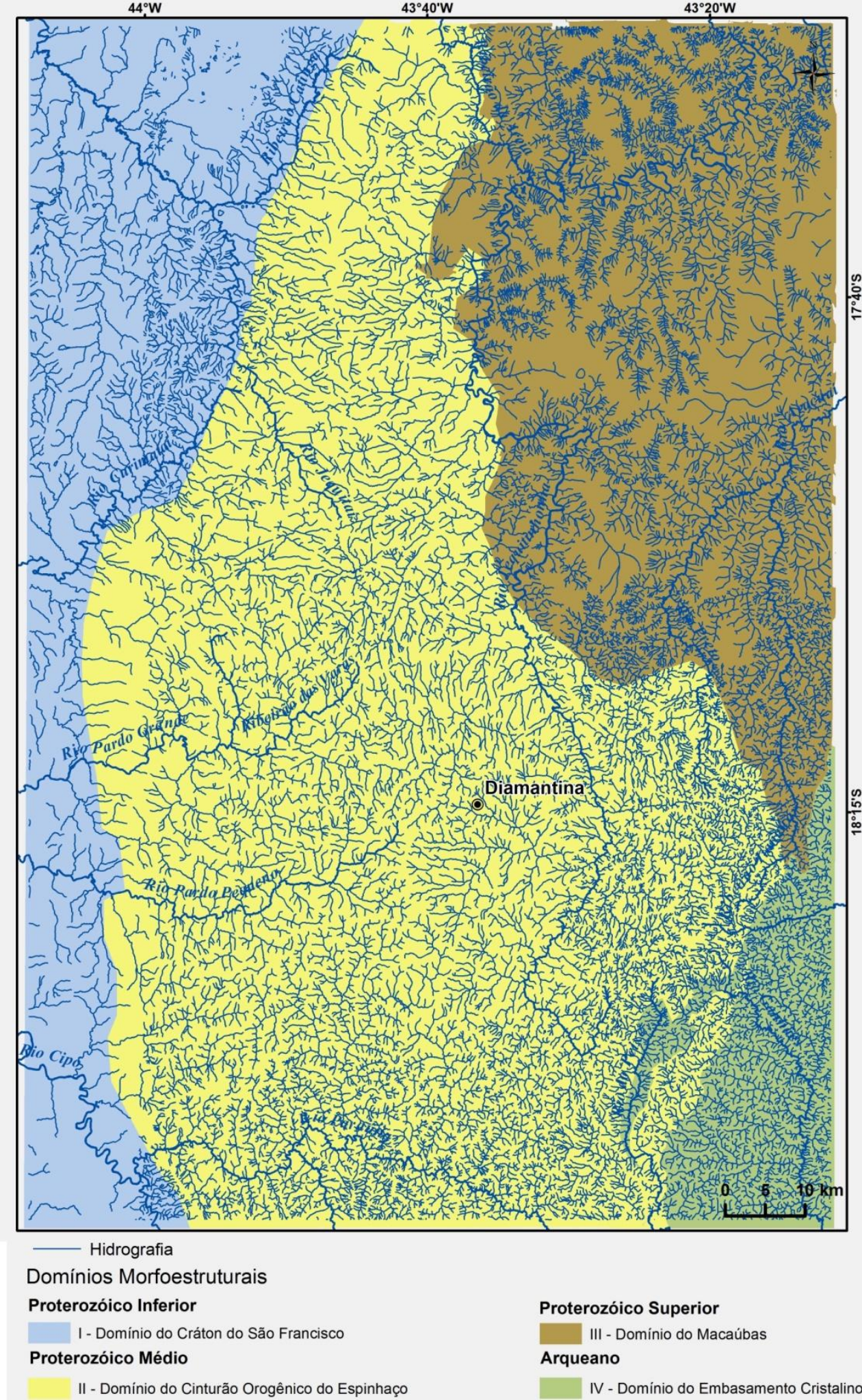

Fig. 2 - Mapa Morfoestrutural do Espinhaço Meridional e do seu entorno.

Constitui, portanto, uma estrutura sedimentar, com graus deformações que diminuem na medida em se afasta do contato com orógeno do Espinhaço. Isto condiciona a ocorrência de padrões de drenagem paralelos, como pode ser observado no mapa dos domínios morfoestruturais (Fig. 2), no qual, além da divisão em grupos litoestruturais, foram também plotados os lineamentos, falhas e fraturas mais importantes, além da drenagem. Já no contato do limite cratônico com o orógeno, as rochas do Grupo Bambuí encontram-se bastante deformadas pela orogênese do Brasiliano (600-520 $\mathrm{Ma})$, o que explica a direção N-S dos lineamentos, seguidos também pela drenagem (Fig. 2). 
O Ciclo Brasiliano que gerou os limites cratônicos, estruturou o segundo Domínio, denominado de Orógeno do Espinhaço, datado do Proterozóico Médio (Fig. 2). Para efeitos do presente mapeamento, nele foram incluídas as áreas das rochas do Grupo Costa Sena Indiviso, formadas principalmente por quartzo xisto e quartzo mica xisto, e ainda as das rochas granito-gnaíssicas do cristalino retrabalhado, datadas do Arqueano e denominadas de Complexo de Gouveia (Knauer,1990).

O padrão mais marcante dessa orogênese (600$520 \mathrm{Ma}$ ) corresponde à presença de falhas de empurrão orientadas no sentido N-S e NNW-SSE. A compressão se deu, de acordo com Almeida Abreu et al. (1994), de E para W, sendo que o grau de deformação cresce de $W$ para $E$. Esse padrão condicionou o Espinhaço como uma unidade de relevo com características próprias. Essa unidade é marcada por feições herdadas desses esforços compressivos que, atuando sobre material em grande parte de natureza rúptil, gerou dobras, falhas, fraturas e lineamentos diversos que são, juntamente com intrusões metabásicas, sob forma de sills, stocks e diques, identificáveis em todos os mapas elaborados. Mais ainda, esse evento afetou a disposição entre as camadas de diversas litologias, o que também interfere na elaboração do relevo, gerando, assim, os contatos do orógeno com outros domínios morfoestruturais marcados por desníveis altimétricos consideráveis, caracterizados por degraus erosivos, porém de controle lito-estrutural, como é o caso das bordas oeste, mais preservada, e a leste, mais difusa e recortada.

As estruturas de grandes dobramentos ainda parecem ter exercido influência sobre a direção, bem como no padrão da drenagem do maciço (Augustin, 1995a). A maior parte dos rios tem direção S-N/N-S (Fig. 4) seguindo aparentemente um controle exercido pelos eixos dos sistemas dobrados de sinclinais e anticlinais com grande raio de envergadura. Os fraturamentos originados durante os processos de dobramento foram inicialmente aproveitados pela drenagem que, ao encaixar e abrir vales contribuiu para a retirada parcial dessas dobras.

Uma segunda direção preferencial pode ser observada no mesmo mapa da figura 2: de oeste para leste e de leste para oeste, seguindo falhas transcorrentes (Augustin, 1995a). Ainda é possível a identificação de uma terceira componente na orientação da drenagem: o encaixamento da drenagem ao longo de intrusões de rochas metabásicas, algumas associadas a falhas e fraturas.

Nesse Domínio, o do Orógeno do Espinhaço, prevalece o padrão retangular secundado pelo de treliça, típicos de áreas submetidas às deformações tectônicas, principalmente em rochas rúpteis como é o caso dos quartzitos (Fig. 2). As deformações de origem tectônica respondem pela presença de estruturas como falhas, que muitas vezes interceptam lineamentos, além da presença de fraturas e de juntas, que são utilizadas pelos cursos de água, dando à drenagem um padrão retangular. De acordo com Twidale (2004), as formas em treliça ocorrem onde afloramentos de rocha são lineares, o que é o caso de áreas de deformações de sentido $\mathrm{N}$ $S$ que ocorrem na porção próxima a escarpa oeste, ao longo de quase toda sua extensão, até o canal do Rio Jequitaí.

Já no Subdomínio do Embasamento Cristalino Remobilizado, datado do Arqueano (Fogaça, 1996), e ainda em parte do Domínio do Orógeno do Espinhaço, remobilização cujas feições foram, ao longo do tempo, em grande parte atenuadas e sobrepostas pelo controle litológico de rochas predominantemente pouco porosas, o que permite o desenvolvimento de uma drenagem do tipo dendrítico, ou arbóreo. A retirada das camadas superiores, quartzíticas, do anticlinório, expôs as rochas remobilizadas do embasamento, conhecidas como Complexo de Gouveia canalizando também as drenagens adjacentes e levando ao desenvolvimento de forma semicircular na área da Depressão de Gouveia.

Em alguns trechos, os cursos de água podem apresentar mudanças bruscas de direção, formando praticamente ângulos retos e, dando à drenagem, localmente, uma aparência de padrão retangular. Essas mudanças são, em geral, controladas por fraturas e sistemas de juntas no caso das rochas do Complexo de Gouveia, que faz parte do Sub-Domínio do Sistema Orogênico da Serra do Espinhaço Meridional (Fig. 2).

O Domínio do Embasamento Cristalino, no limite sudeste do Espinhaço, é formado por rochas predominantemente do Arqueano, principalmente granitóides, das quais se destacam as do Grupo Guanhães e rochas intrusivas da Suíte Borrachudos. Esse complexo de rochas granito-gnaíssicas e intrusivas, torna-se espacialmente mais representativo na medida em que se afasta do limite com o orógeno, onde cede lugar, à oeste, às rochas do Supergrupo Espinhaço, do Proterozóico Inferior/Médio (Kanuer \& Grossi Sad, 1996).

No embasamento cristalino, nos subdomínios Rochas do Complexo Guanhães e das Rochas do Complexo (SUÍTE) Borrachudo, observa-se um padrão dendrítico predominante, típico desse tipo de litologia, em climas úmidos, cuja drenagem, em função da baixa permeabilidade das rochas, tende a desenvolver um grande número de confluências. A 
presença de fraturas e juntas nesse domínio acaba por imprimir, localmente, um padrão retangular de drenagem. Nas proximidades da ocorrência das rochas do Supergrupo Espinhaço, volta a predominar a influência dos dobramentos e direção do mergulho das camadas, com a drenagem principal, incluindo a do rio Jequitinhonha, apresentando direção N-S.

O Domínio do Macaúbas ocupa a porção nordeste da área mapeada. Embora seja constituído também por rochas do Supergrupo Espinhaço, especialmente quarzitos de granulometria e composições mineralógicas variadas, ele é caracterizado pelo predomínio de rochas do Grupo Macaúbas, formadas por metassedimentos com composições quartzíticas, datados do Proterozóico Superior. A característica geológica mais marcante nesse domínio, do ponto de vista geomorfológico, é a presença de extensas acumulações detríticas coluviais, datadas do Terciário-Quaternário, e identificadas como superfícies de aplainamento no mapeamento geológico da Folha Curumataí (Noce \& Fogaça, 1996). Sobre ela, a intensa dissecação promovida pelos sistemas de drenagem, elaborou uma sucessão de chapadas e chapadões, com vertentes abruptas. Típicas de estruturas sedimentares em geral monoclinais, essas formas de relevo ocorrem, nesta área, a rigor em estruturas dobradas e falhadas, mas são condicionadas por eles e sim pelas coberturas detríticas que são encontradas recobrindo rochas diferenciadas do Domínio do Macaúbas.

O padrão da drenagem nesse domínio é predominante dendrítico, com tendência ao paralelo nas áreas onde 0 substrato das rochas metassedimentares não se encontra revestido por sedimentos detríticos. O rio Jequitinhonha que tem suas nascentes do domínio do Espinhaço, correm em direção norte margeando o contato entre esses dois Domínios: do Orógeno do Espinhaço e do Macaúbas, dissecando a borda leste do orógeno e condicionando o retrabalhamento do relevo elaborado sobre das rochas metassedimentares do Grupo Macaúbas, bem como de sua sequência detrítica.

\section{2 - Mapa hipsométrico}

O mapa hipsométrico (Fig. 3), o de classes de declividade (Fig. 4), juntamente com os de orientação (Fig. 5), que se complementam, apresentam um conjunto de informações que possibilitam uma visualização mais apurada da dinâmica passada e presente na área estudada.

Análise do mapa hipsométrico, representado na Figura 3 mostra de maneira clara que as maiores altitudes da área mapeada ocorrem no interior do maciço do Espinhaço, enquanto suas bordas são topograficamente mais baixas, evidenciando a atuação de processos erosivos muito mais eficazes nas áreas dos Domínios do Cráton do São Francisco e no Domínio do Macaúbas, seguidos pelas áreas dos Domínios do Embasamento Cristalino, a sudeste.

No maciço do Espinhaço, a presença de diversos níveis altimétricos foi interpretada por King (1956), como remanescentes de aplainamentos resultantes de recuo paralelo das escarpas que teriam gerado, do Cretáceo Inferior a Médio, a elaboração de três grandes pediplanos na área do Espinhaço: a superfície Gondwana que estaria representada pelos níveis de $1800 \mathrm{~m}$ de altitude; a Pós-Gondwana, com a de $1400 \mathrm{~m}$, e a Sul Americana, com cotas entre 1100 $1200 \mathrm{~m}$.

Essa interpretação contrasta com as feições hoje sendo elaboradas, que apontam para uma incisão ativa da drenagem em especial no Domínio do Macaúbas e no seu entorno, indicando que o aparente desmonte das estruturas formadas por rochas mais resistentes tem um componente climático, com o domínio de condições de disponibilidade de água no sistema, pelo menos a partir da elaboração do último pediplano identificado por King.

É possível observar a partir da análise da Figura 3 , que as altitudes predominantes em toda a área mapeada são aquelas entre 798 e $1200 \mathrm{~m}$ e, no Espinhaço Meridional, as compreendidas entre 1100 e $1200 \mathrm{~m}$.

Também é possível identificar patamares altimétricos intermediários entre as cotas mais elevadas (acima de $1200 \mathrm{~m}$ ) e aquelas menos elevadas (abaixo de 900m), com valores entre 1100 e acima de $1400 \mathrm{~m}$ apenas no Espinhaço. Este intervalo ocorre nas bordas das áreas mais elevadas formando uma "franja" que tende a tornar-se mais representativa na porção superior, entre as bacias do Ribeirão das Varas, afluente do Rio Pardo Grande, e o meio curso do Rio Pardo Pequeno, contornando os limites da Depressão Gouveia, dominada pelas cotas 1200 e $886 \mathrm{~m}$. De maneira mais contínua, no entanto, esse intervalo altimétrico caracteriza toda a porção noroeste do Espinhaço, contornando a zona do platô sententrional. São áreas indicadas neste mapeamento como Erosivas Remanescentes e correspondem a extensos platôs cujo substrato rochoso é formado por quartzitos da Formação Galho do Miguel, ricos em areia pura e, nestas áreas, pouco recortada por intrusões de rochas metabásicas e básicas (Noce \& Fogaça, 1996). 

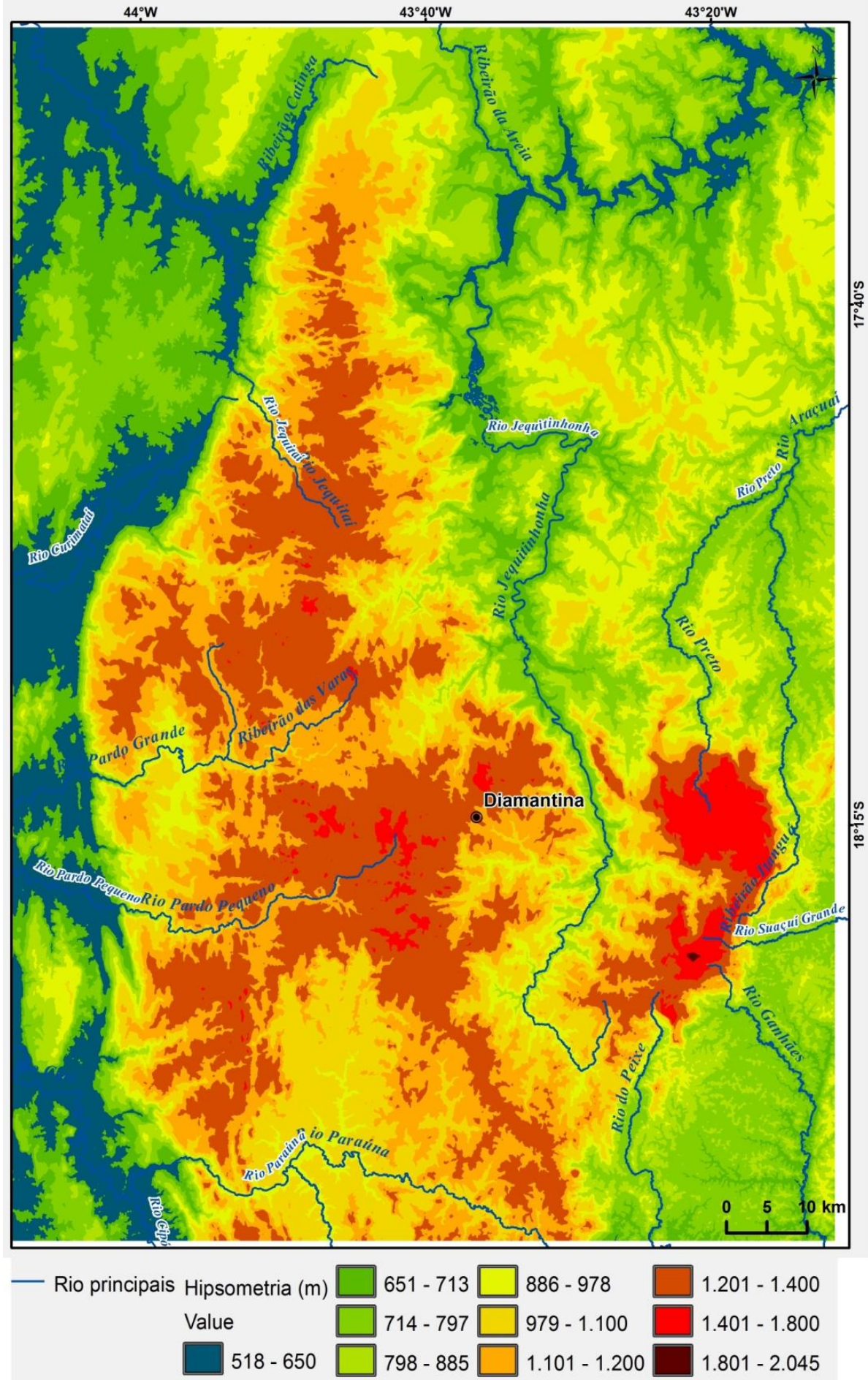

Fig. 3 - Mapa Hipsométrico do Espinhaço Meridional e do seu entorno

As menores altitudes predominam espacialmente, de maneira mais contínua na área do Domínio do Cráton do São Francisco. Algumas porções mais elevadas, mas com altitudes regularmente homogêneas entre 651 e $797 \mathrm{~m}$, indicam formas de relevo de topo planos e relativamente extensas, que se sobressaem em áreas dominadas por relevo baixos, compreendidos na cota de 518 a $650 \mathrm{~m}$.

Nos dois outros Domínios, do Macaúbas e do Embasamento Cristalino, localizados a leste do
Espinhaço, observa-se o predomínio de áreas com altitudes entre 886 e $979 \mathrm{~m}$, representando topos de vertentes longas e muito dissecadas, localizadas em cotas de 651 a $797 \mathrm{~m}$. As altitudes mais baixas, de 518 a $650 \mathrm{~m}$, encontram-se restritas aos fundos de vale, em especial no Domínio do Macaúbas, enquanto no Embasamento as altitudes predominantes estão na faixa dos intervalos de classe entre 798 e $978 \mathrm{~m}$, indicando possivelmente efeitos não só da orogênese, como influência também litológicas e estruturais das rochas do 
Supergrupo Espinhaço presentes nesta porção, uma vez que, do ponto de vista de intemperismo, as rochas migmatíticas desse Domínio favoreceriam o desenvolvimento de mantos de alteração profundo e a ocorrência de processos de erosão, acentuando, desta maneira, a dissecação do relevo.

\section{3 - Mapa de classes de declividade}

O mapa de declividade, apresentada em graus, indica a existência de seis (6) classes de declividade (Fig. 4). Essas seis classes foram consideradas como representativas das diferenças de inclinação do relevo verificadas nos vários domínios analisados.

Percebe-se a dominância das cores verde e amarelas, correspondentes às classes de 0 (zero) a 9 (nove) graus, com um aumento das classes acima de $12^{\circ}$ apenas nas bordas erosivas, à oeste, no contato do domínio do Cráton do São Francisco com o Orógeno Espinhaço, quanto no seu contato leste com o Domínio do Macaúbas, na região nordeste do mapa, onde também ocorre uma escarpa, a da borda leste.

Marcam ainda alinhamentos N-S, que acompanham a borda oeste, formando serras, em especial na porção sul do Espinhaço. As declividades são mais acentuadas também ao longo de vales encaixados, como os dos Rios Pardo Grande e Pardo Pequeno, Jequitinhonha, Paraúna e Jequitaí. Para o norte do maciço, predominam as tonalidades de verde, indicando relevo mais aplainado, sem que esta definição tenha conotação genética.

As declividades mais acentuadas, acima de 9ㅇ, encontram-se agrupadas em áreas que marcam os limites oeste e leste do orógeno, ao longo dos vales dos principais cursos de água, acompanhando alinhamentos $\mathrm{N}-\mathrm{S}$, com rupturas acentuadas de declive, bem como área localizada na porção central do maciço que funciona como um grande interflúvio entre as drenagens das bacias dos Rios Jequitaí, Jequitinhonha e Pardo Grande. Este corresponde a uma extensa área com altitudes acima de $1400 \mathrm{~m}$, bem preservada e claramente identificável no mapa hipsométrico da figura 3.

\section{4 - Mapa de orientação do relevo}

O mapa de orientação do relevo (Fig. 5) mostra as direções predominantes das vertentes com relação as suas faces expostas.

As cores, amarelo e verde são predominantes, indicando que as vertentes encontram-se preferencialmente voltadas para leste ou oeste.

As orientações das vertentes refletem, em grande parte, deformações tectônicas ocorridas no orógeno, com esforços compressivos de leste para oeste, criando dobramentos com direção N-S e exposição das camadas nas direções leste e oeste (Fig. 5). A erosão, tanto de encosta, como a fluvial, vêm ao longo do tempo expondo e esculpindo essas camadas e formando vertentes com afloramentos rochosos em escarpas mais abruptas nos fronts, que são voltados para oeste, e menos abruptas nos seus reversos, voltados para leste (Fig. 4). Esses últimos são mais longos, evidenciando também a dificuldade de entalhe desses reversos pela drenagem. A exposição das vertentes ainda é mais pronunciada longo das duas bordas, oeste e leste, que marcam o contato do Espinhaço com os outros Domínios: o do Cráton do São Francisco a oeste e com os do Macaúbas e do Embasamento Cristalino, a leste.

As cores, vermelha e azul, representando as exposições com direção norte/sul respectivamente, são espacialmente menos representativas, encontrando-se associadas à ocorrência de fraturas, falhas, lineamentos e intrusões. A cor vermelha é mais comumente encontrada no Domínio do Espinhaço, provavelmente indicando a exposição decorrente do elevado grau de fraturamento das rochas mais rúpteis, características do Supergrupo Espinhaço. Também parece estar associada a uma progressiva queda altimétrica em direção ao norte do maciço, revelada pelo mapa da figura 4, o que tende a expor mais as vertentes voltadas para o norte. A azul ocorre mais densamente no Domínio do Macaúbas, no nordeste da área mapeada, e na porção noroeste do maciço, podendo estar associada à presença de vales muito encaixados, no primeiro caso e à ocorrência de superfície topograficamente mais baixa, no segundo caso (Fig. 5). A exploração de fraturas, falhas e de outras feições estruturais pela drenagem auxilia na exposição das vertentes para norte ou para sul.

\section{5 - Unidades morfoesculturais do espinhaço} meridional

As principais feições identificadas apresentadas na Figura 6a, 6b e 7, correspondem aos elementos discutidos abaixo. As principais unidades de forma e, portanto, da morfoescultura (Ross, 1992), foram organizados em duas unidades principais:

1 - Feições Erosivas, que por sua vez foram subdivididas em:

\section{- Superfícies Erosivas Remanescentes;}

- Superfícies Erosivas Retrabalhadas.

\section{2 - Feições Deposicionais, subdividida em:}

\section{- Áreas Deprimidas;}

- Áreas de Influência Imediata Fluvial.

Cada Unidade, por sua vez, foi subdividida em subunidades nas quais foi possível a identificação de formas semelhantes de formas de relevo. 


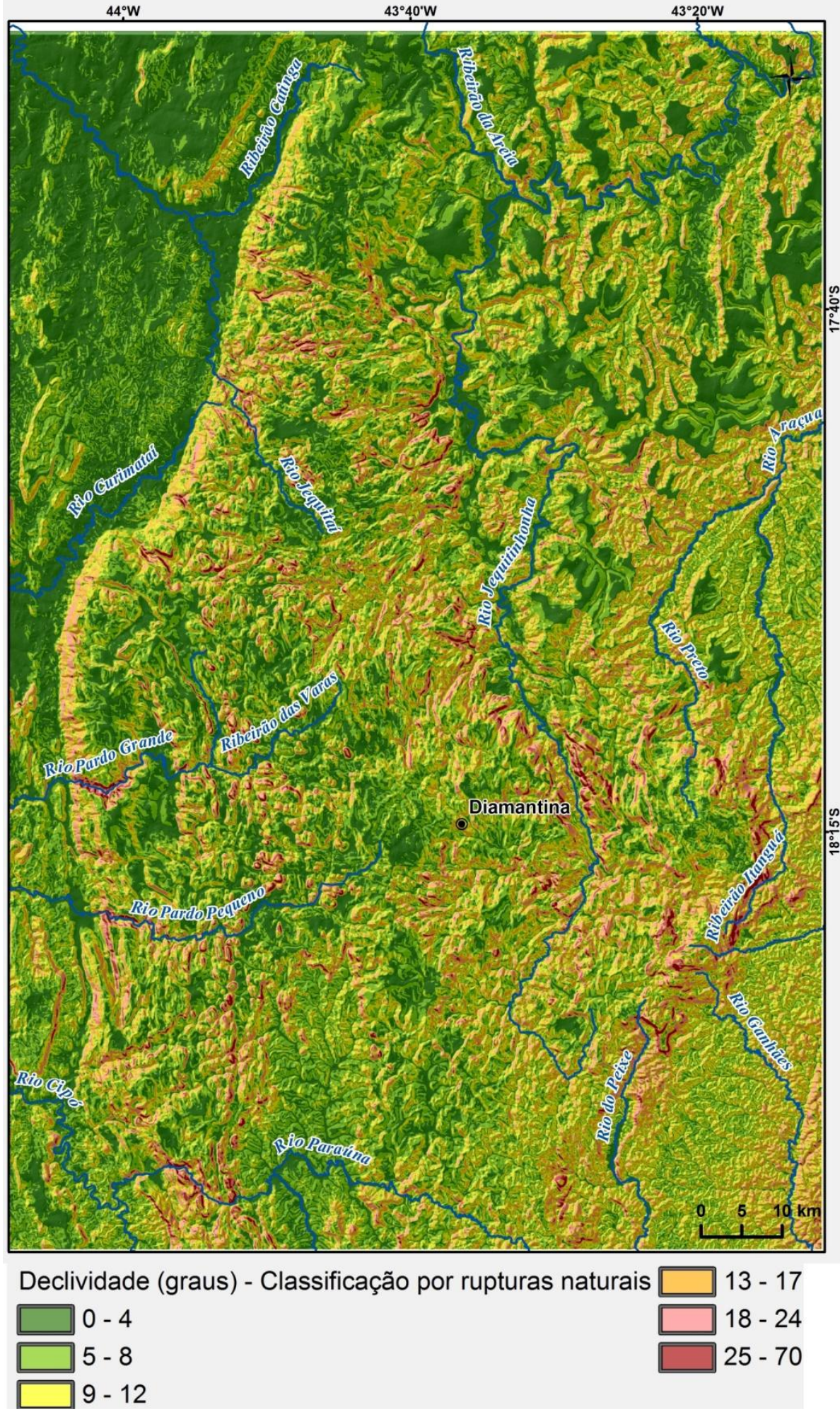

Fig. 4 - Mapa de Classes de Declividade do Espinhaço Meridional e do seu entorno

\section{6 - Análise Morfoestrutural e Morfoescultural}

O mapa dos Domínios Morfoesculturais (Fig. 6a e 6b) individualiza os subdomínios morfoesculturais, em função da predominância dos processos na elaboração das formas de relevo, ou seja, se estes são mais de erosão, ou de agradação. Embora ocorram mais formas erosivas do que deposicionais, as áreas erosivas também contêm porções deposicionais, principalmente onde o intemperismo leva à desagregação das rochas do Supergrupo Espinhaço, em especial as de granulometria grossa, como as areias. 


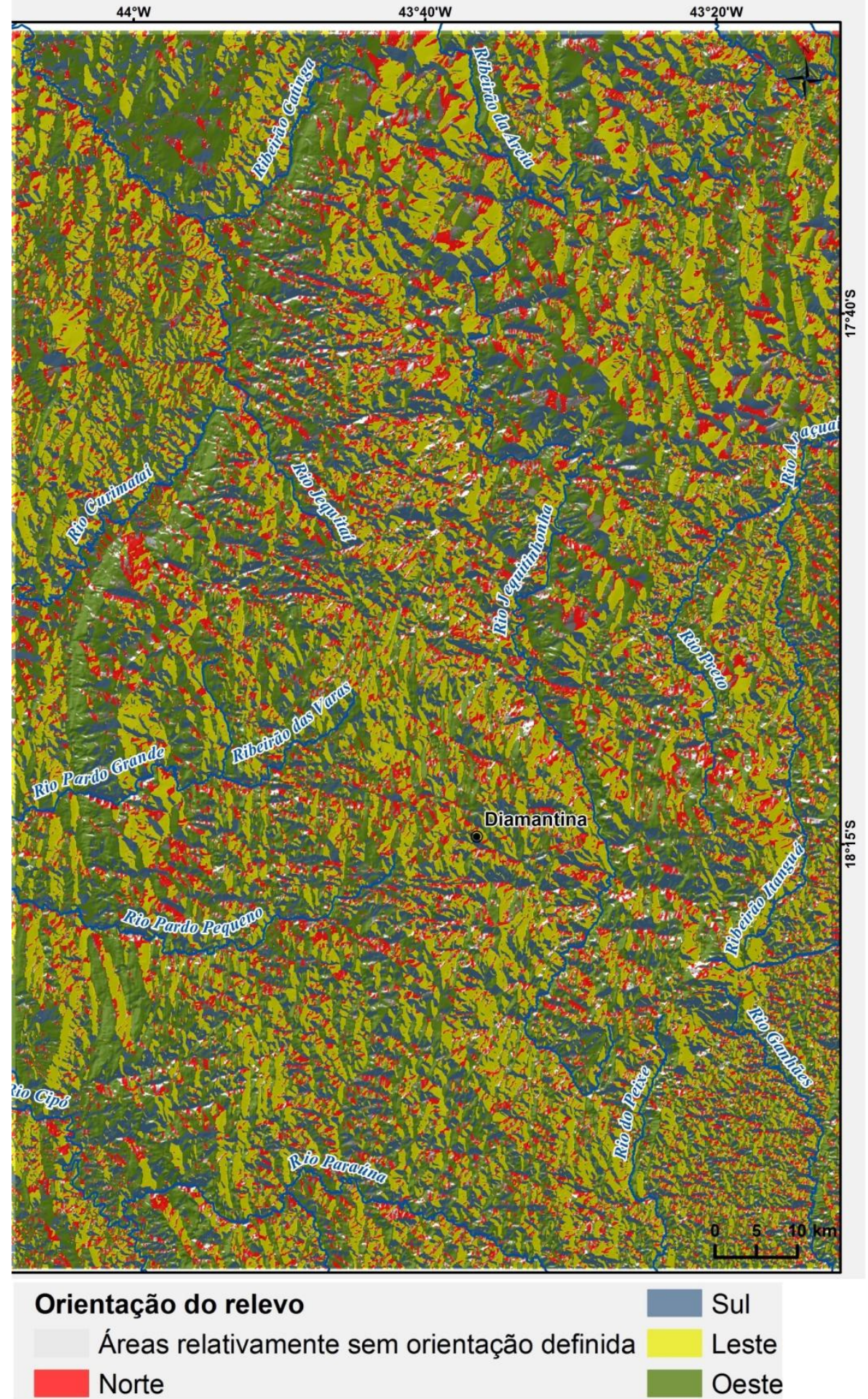

Figura 5- Mapa de Orientação do Relevo do Espinhaço Meridional e do seu entorno.

Por causa dos fatores litológicos e, secundariamente, dos estruturais como direção do mergulho das camadas e sobreposição de litologias mais ricas em quartzo com aquelas menos ricas, a evolução do relevo nas áreas de predomínio de rochas do Espinhaço revelam feições de superfícies erosivas predominantes sobre aquela deposicionais.
São, contudo de duas ordens: as remanescentes e as retrabalhadas (Fig. 6). As remanescentes são formadas por topos achatados ou não, dominados por afloramentos, que marcam com certa regularidade todo o Espinhaço e parte das chapadas e chapadões do Grupo Macaúbas, a nordeste da área mapeada. 


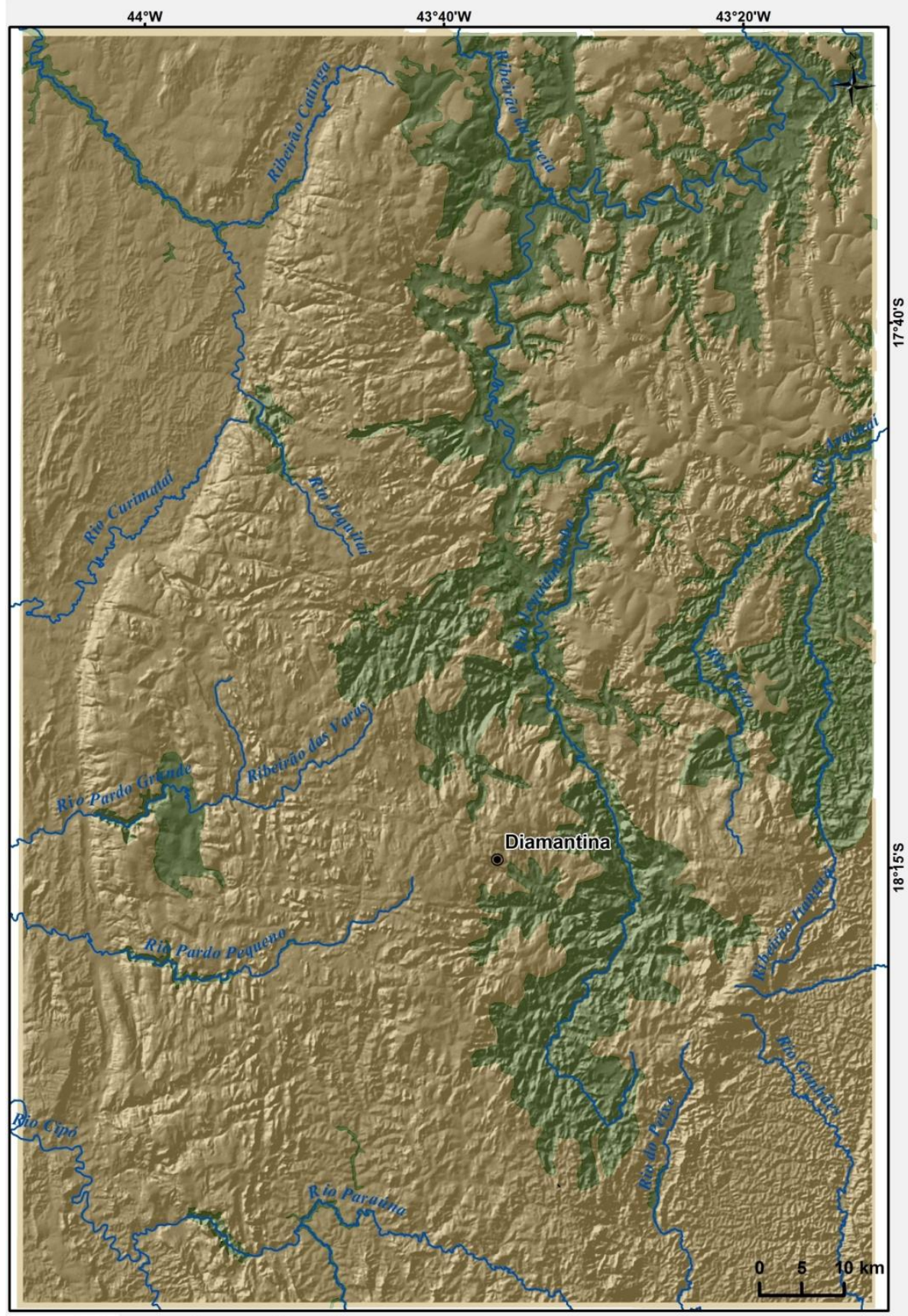

\section{Domínios morfoesculturais}

\section{1 - Feições Erosivas \\ 2 - Feições Deposicionais}

Fig. 6a-Mapa das Unidades Morfoesculturais do Espinhaço Meridional

As retrabalhadas correspondem às áreas de incisão da drenagem, ou aquelas resultantes de erosão dos afloramentos, independentes das feições originais resultantes da orogênese, como sinclinais, anticlinais e hog-backs. Formam a área mais representativa de todos os Domínios Morfoestruturais e refletem a atuação de processos erosivos e fluviais que atuam no sentido do "desmonte" das grandes estruturas.

A influência da morfoestrutura, no entanto, se faz presente nas mais distintas feições mapeadas neste trabalho (Figs. 2, 3, 4, 5, 6a, 6b e 7). Contudo, feições de detalhe, como estruturas falhadas ou dobradas, tendo em vista suas especificidades geológicas, nem sempre se fazem representar em termos de formas de relevo. Essa é o caso da borda oeste do Espinhaço (Figs. 3 e 4), caracterizada por um desnível médio de $400 \mathrm{~m}$, pode ser atribuído a erosão das rochas metapelíticas do Grupo Bambuí, mesmo considerando a presença de uma falha de empurrão em sua porção sul, e outra, normal, em sua porção norte (Knauer et al., 2011). 


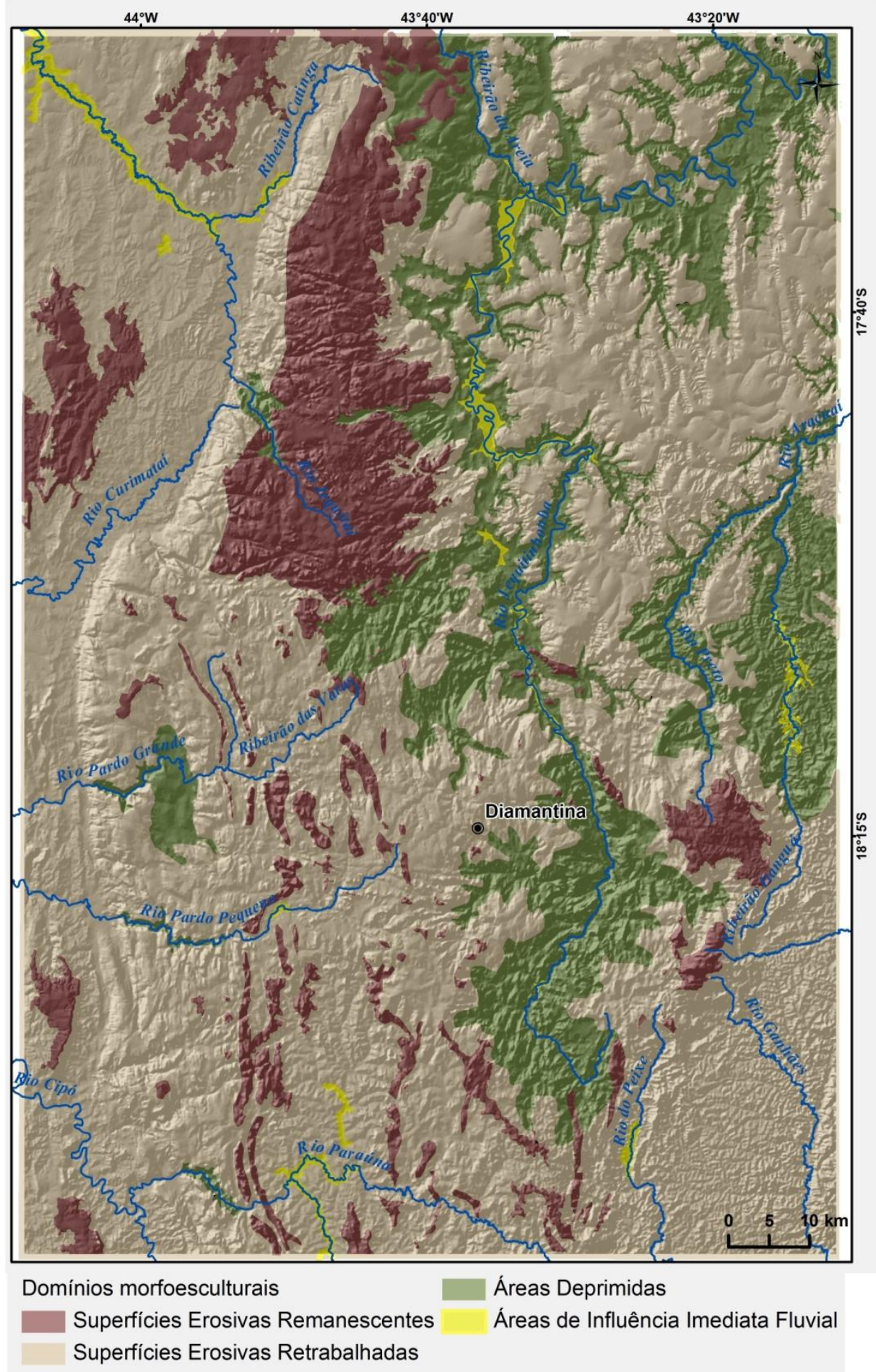

Fig. 6b-Mapa das Subunidades Morfoesculturais do Espinhaço Meridional

Essa escarpa erosiva é relativamente pouco dissecada pela drenagem que desce do maciço do Espinhaço, e tem dificuldade de cortar as rochas, em especial, as da Formação Galho do Miguel em função da sua composição de até $95 \%$ de quartzo puro (Fogaça, 1978, apud Augustin, 1995a). Exceção é feita pelos Rios Pardo, Paraúna e Jequitaí e o Ribeirão Catinga. Já a borda leste, também marcada por falha de empurrão, de caráter de zona proximal da colisão, segundo Saadi (1995), encontra-se parcialmente erodida, não apresentando contigüidade espacial, como a observada na borda oeste. Parte desse desmonte foi efetuada pela drenagem, hoje realizada pelos rios Jequitinhonha e Preto, e Ribeirões Caeté-Mirim, das Pedras e do Inferno.

Os esforços compressionais do Evento Brasiliano, com vergência para oeste, também são responsáveis pela presença de sequências de cristas com direção 
N-S, que acompanham a borda oeste da Serra, em especial em sua porção mais sul (Figs. 4 e 5). Essas cristas são formadas, em sua sequência mais representativa, por afloramentos quartzíticos, datados do Proterozóico Médio, de diversas Formações que compõem o Supergrupo Espinhaço, mas com destaque para a Formação Galho do Miguel, composta por quartzitos puros, e da Formação Córrego dos Borges, também de quartzitos, mas com composição mais micácea (Knauer et al., 2011; Noce \& Fogaça, 1996; Costa et al.,2011). Essas sequências apresentam inclinações em torno de 30 으, o que não permite classificá-las como hog-backs. As cristas apresentam duas feições predominantes: os fronts, mais abruptos, voltados para oeste e os reversos, mais suaves, para leste. Entre essa sucessão de cristas, é comumente encontrado material deposicional, depositado pela alteração dos afloramentos, mas ainda não retirado pelo sistema de drenagem (Fig. 7). Na medida em que se avança para o interior do Domínio Espinhaço, a drenagem torna-se aparentemente mais eficiente, formando vales mais profundos, o que se reflete também no aumento da declividade em resposta à incisão (Fig. 2) e na retirada dessas deposições, fazendo com que o relevo seja considerado como erosivo retrabalhado (Fig. 6a, 6b).

A escarpa propriamente dita (Fig. 7), por sua vez, contem rochas do Grupo Macaúbas Indiviso, datado

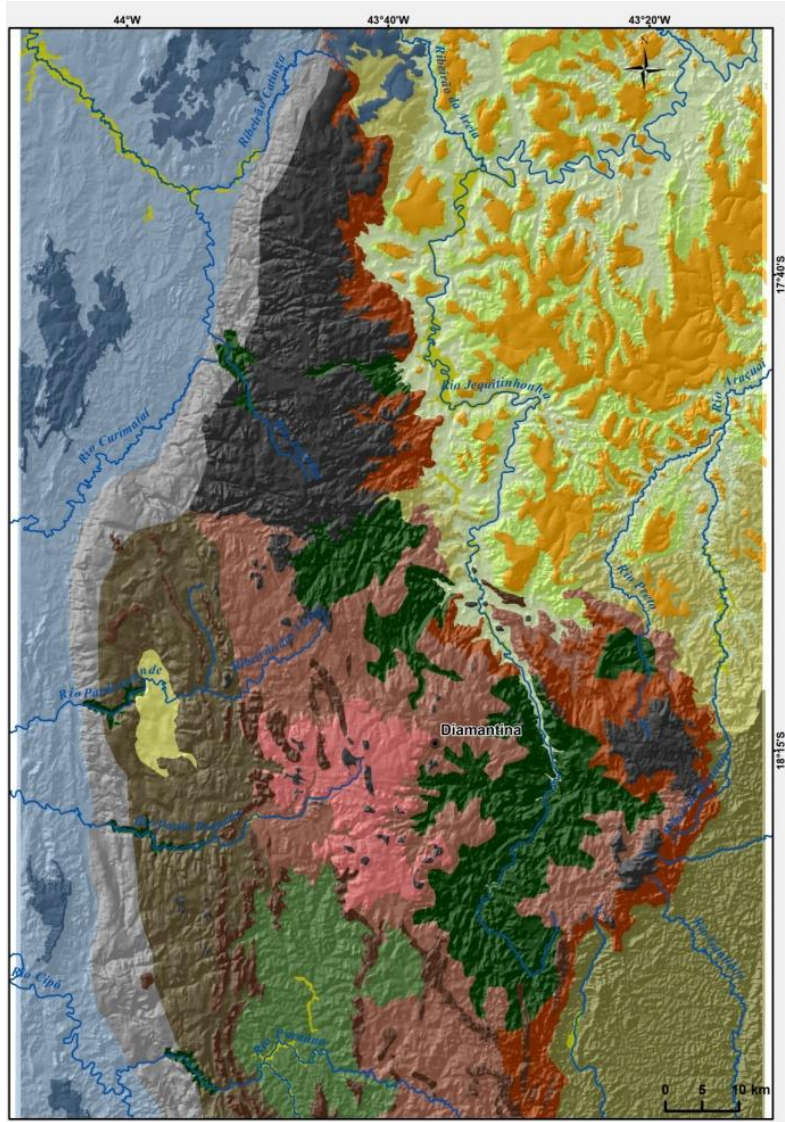

do Proterozóico Superior (Noce \& Fogaça, 1996), formado por quartzitos impuros e puros, de granulometria fina. Ela forma uma escarpa com diferenças altimétricas médias de $400 \mathrm{~m}$ com relação ao relevo do Domínio Cratônico do São Francisco, a oeste. Representa, assim, um relevo erosivo remanescente, com cotas altimétricas com pequeno caimento de sul para norte.

Porém ao norte do rio Pardo, especialmente após o vale do Rio Jequitaí, esse alinhamento estrutural cede lugar à presença de um grande platô, identificado por Saadi (1995), como Planalto Setentrional, com afloramentos quartzíticos rebaixados da Formação Galho do Miguel (Fig. 6). Diferentemente de outras áreas mais ao sul, caracterizadas pelas sequências de cristas descritas acima, essa unidade, cuja base é formada por quartzitos da Formação Galho do Miguel é espacialmente contínua, recortadas por fraturas e falhas, com densidade menor de intrusões de rochas metabásicas, o que pode responder por sua evolução mais homogênea, formando quase um platô erosivo, no qual se destacam os afloramentos de quartzito, intercalados por deposições de materiais arenosos, pedogenizados ou não (Fig. 6a).

Uma das feições comuns nas áreas próximas aos afloramentos rochosos é a presença de rampas que, em geral, apresentam quatro subunidades, não

\section{Legenda}

- Rio principais

Áreas de Influência Imediata Fluvial

Planícies fluviais

Fundos de vales e terraços Quaternários

Áreas Deprimidas de Domínio Fluvial

Alveolos flúvio-coliviais

Baixas vertentes

Sistema de vertentes e vales encaixados

Superfícies Erosivas Remanescentes

Chapadas e chapadões com topos aplainados

Compartimento com alinhamentos linhas de cristas

Linhas de cristas residuais

Platôs e relevos residuais quartzíticos

Relevo residual da depressão do São Francisco

Superficie erosiva de Guinda e Diamantina

Vertentes em rampas estruturalmente condicionadas

\section{Superfícies Erosivas Retrabalhadas}

Colinas convexas e policonvexas da depressão de Gouveia Colinas convexas e policonvexas do embasamento cristalino Escarpa erosiva descontínua (borda leste)

Escarpa erosiva contiinua (borda oeste)

Morros de topos achatados e vertentes suaves

Rebordo festonado de chapadas e chapadões 
individualizadas no mapeamento em função da escala: o afloramento rochoso, o knick point marcando o contato entre o afloramento e a rampa, a própria rampa, e o canal dos córregos, ou ribeirões. Há situações em que os afloramentos de quartzito, que embora não sejam os únicos são os dominantes na área do orógeno do Espinhaço, formam paredões de até $100 \mathrm{~m}$ de altura, antes de ser interrompido pelas rampas. Essas têm caimento suave, abaixo de $5^{\circ}$, podem atingir vários quilômetros de extensão, formadas por material predominantemente de granulometria de areia. A ausência de blocos acumulados na borda de contato do afloramento com a rampa arenosa, deposicional, aponta para a predominância de processos que levam á desagregação das rochas do afloramento por processos que incluem o intemperismo químico.

O Domínio do Espinhaço Meridional também açambarca unidades estruturais importantes, como sinclinais, anticlinais e hog-baks, que não serão individualizados como unidade morfoesculturais em razão da escala do trabalho, e do fato de que parte destes já foi parcialmente erodida pela incisão da drenagem. 0 processo erosivo dessas estruturas deu origem a extensas áreas caracterizadas por ocorrência de afloramentos rochosos e rampas, como descritas acima, vales encaixados ou escarpas, caracterizadas por declives em acentuados, muitas vezes em forma de degraus, ou de alinhamentos estruturais, denominados localmente se serras. Esse é o caso das Serras do Engenho, dos Altos Currais e do Tigre.

O processo de erosão, ao longo do eixo do anticlinório de Gouveia, por outro lado, provocou inversão de relevo, com a retirada das camadas superiores e exposição das rochas do Complexo Granítico de Gouveia, em situação de depressão (Fig. 6). Para esta depressão, denominada por Plufg (1967) de Depressão de Gouveia, converge a drenagem das porções mais elevadas, de domínio das rochas do Supergrupo Espinhaço, caracterizando-a como feição erosiva, mas retrabalhada, com depósitos aluviais pouco representativos na escala do presente mapeamento. As unidades de relevo predominantes são, contudo, vertentes convexas e policonvexas, resultantes da incisão da drenagem. A mesma forma de relevo pode ser identificada no Domínio do Embasamento Cristalino, no Vales dos Rios dos Peixes e Guanhães, demonstrando, assim, a importância da litologia na definição do padrão de formas de relevo, sob condições climáticas semelhantes.

Portanto, as Unidades de Superfícies Erosivas, retrabalhadas ou não, estão presentes em várias altimetrias, dominando quase toda a área mapeada, indistintamente da lito-estrutura. Esse fato aponta para uma prolongada e intensa evolução das formas de relevo sob condições predominantemente úmidas e quentes desde, pelo menos, final do Cretáceo (Augustin et I., 1994). Isto não significa que não tenham ocorrido episódios de climas mais secos, e mesmo frios. No entanto, pelos indícios apresentados pelas formas de relevo, estes não tiveram desde o Cretáceo, duração temporal, ou intensidade suficiente, para definir um padrão evolutivo associado aos climas com menor disponibilidade de água no sistema.

Os sistemas de superfícies erosivas compõem, assim, a porção mais representativa desse longo processo de perda física e mecânica das rochas que formam as maiores unidades de relevo do Espinhaço Meridional e do seu entorno. Representa também o trabalho de dissecação de um sistema de drenagem que tem imprimido sua marca no desmonte da estrutura tanto do orógeno, quanto de outras unidades morfoestruturais, em especial aquelas dos domínios de rochas menos permeáveis, como as do embasamento cristalino (Fig. 2). Percebe-se através dos mapas das Figuras 3 e 4 que esse desmonte é, aparentemente, mais eficiente de leste para oeste, com as superfícies mais dissecadas ocorrendo principalmente no entorno da borda leste do Espinhaço, onde são encontradas as maiores evidências de dissecação.

Portanto, como subunidades mapeadas no mapa síntese, destacam-se:

\section{A) Superfícies Erosivas Remanescentes}

a) Relevo Residual da Depressão do São Francisco: tem como substrato rochoso a Formação Serra de Santa Helena, constituem morrotes ou morros tubuliformes, com topos relativamente planos e encostas abruptas, com incisão de ravinas;

b) Compartimento com Alinhamentos de Cristas: são formas geradas por remanescentes de dobras, com fronts voltados para oeste e reversos para leste. Encontram-se mais representadas nas porções sudoeste do domínio do Orógeno Espinhaço e tendem a desaparecer cedendo lugar aos platôs quatzíticos, na sua porção setentrional; a inclinação das camadas, abaixo de $30^{\circ}$, não permite classificar essas estruturas inclinadas como hog-backs.

c) Platôs Quartzíticos e Relevos Residuais Quartzíticos: constituem superfícies elevadas, mais ou menos planas, típicas do Espinhaço Meridional, nas quais os processos de degradação superam os processos de agradação. Em algumas áreas esses platôs encontram-se muito fraturados, o que dificulta a atuação de processos de dissecação, pois a água de escoamento tende a infiltrar, auxiliada também pela presença de rochas mais porosas do que as das áreas do embasamento cristalino. 
d) Superfície Erosiva de Guinda e Diamantina: áreas topograficamente elevadas do Espinhaço, nas cotas acima de $1000 \mathrm{~m}$, localizadas na porção central da SdEM. Apresenta unidades que contrastam alinhamentos serranos a extensas áreas aplainadas. Uma das suas feições mais características é vertentes constituídas principalmente por afloramentos rochosos, extremamente fraturados em blocos do tamanho de matacões, que apresentam queda, dando as vertentes um aspecto ruiniforme. Às vezes, nas porções mais baixas da base da encosta, apresentam cobertura de Neossolo litólico ou Neossolos quartzo arênicos.

e) Vertentes em Rampas Estruturalmente Condicionadas: constituídas por afloramentos rochosos, que circundam rampas coluviais, pouco espessas, com baixa declividade, porém extensas, formadas pelo intemperismo das rochas aflorantes.

f) Chapadas e Chapadões: formadas pela incisão da drenagem, com cobertura detrítica do TerciárioQuaternário. Apresentam-se ligeiramente inclinada com altitudes entre 750 a 1000 metros (Saadi, 1991; Augustin, 1995a) e com declividades acentuadas. Nos topos, conta com espessos mantos de alteração e a presença, em geral, de solos bem desenvolvidos e laterizados (Augustin, et al., 1998).

\section{B) Superfícies Retrabalhadas}

a) Morros de Topos Achatados e Vertentes Suaves: correspondem a extensas áreas de superfície plana, com baixa gradiente de declividade, modeladas sobre as rochas metapelíticas do Grupo Bambuí.

b) Escarpa Erosiva Contínua (Borda Oeste): escarpa que possui trechos com evolução geológica diferenciada. Ao sul, ocorre falha de empurrão; na sua porção central não foi detectada a presença de falha, e na parte norte, após curva acentuada que a escarpa apresenta para leste, ocorre uma falha normal (Noce \& Fogaça, 1996). A morfologia escarpada da borda, no entanto, decorrente de processos erosivos, não se tratando de escarpa de falha. Parte representativa da escarpa é formada por quartzitos da Formação Galho do Miguel e da Formação Córrego dos Borges (Knauer \& Fogaça, 1996), resistentes ao intemperismo, o que dificulta a incisão dessa borda pela drenagem. Apresenta declividades acentuadas, com desníveis altimétricos médios de 400 metros. A escarpa acompanha toda a borda oeste do Espinhaço, sendo sustentada por quartzitos, embora conte com rochas do Grupo Macaúbas. Possui também características marcantes de front de cavalgamento, no limiar da zona cratônica e da faixa orogênica (Oliveira \& Alkimim, 1994). c) Colinas Convexas e Policonxevas da Depressão de Gouveia: colinas modeladas em granitóides (Complexo de Gouveia). Possuem topos achatados e largos, vertentes longas, que funcionam como divisores de água entre pequenas bacias de drenagem. Essas colinas encontram-se pouco dissecadas pela erosão fluvial, mas com voçorocamento acentuado (Augustin \& Aranha, 2006). É interessante notar que nesta área predominam processos de erosão dispersa e concentrada, mas os de movimento de massa são menos freqüentes, praticamente restritos aos canais das voçorocas (Augustin \& Aranha, 2006).

d) Escarpa Erosiva Descontínua (Borda Leste): relevo estruturado em zona de cavalgamentos e falhamentos de diversas origens, no contexto da zona colisional do orógeno do Espinhaço. Não possui continuidade espacial e encontra-se disposto em diferentes direções. Segundo Saadi (1995), tal configuração da escarpa leste se deve à sua posição no contexto geotectônico da SdEM, bem como da diferença de resistência das rochas.

e) Colinas Convexas e Policonvexas do Embasamento Cristalino: colinas modeladas em granitóides, gnaisses bandados, migmatitos, rochas máficas e metaultramáficas, as quais sofreram a ação da orogenia brasiliana (Uhlein, 1991). Formam topos arredondados e vertentes com declividades relativamente acentuadas, evidenciando incisão pela drenagem.

f) Rebordo Festonado das Chapadas e Chapadões: correspondem às áreas compreendidas entre os topos aplainados das chapadas e chapadões e os vales. Apresentam-se escarpadas, com declividades variando de 13 a $25^{\circ}$, indicando na incisão eficiente da drenagem.

\section{C) Áreas Deprimidas do Domínio Fluvial}

a) Alvéolos Flúvio-Coluviais: zonas de soleiras locais, com retenção de material coluvial e fluvial, muitas vezes resultantes do intemperismo das rochas quartzíticas do Supergrupo Espinhaço. Um exemplo claro na área mapeada é o sinclinal do Rio Pardo Grande.

b) Sistemas de Vales Encaixados: áreas modeladas pela incisão vertical da rede de drenagem em planos de falhas e fraturas, formando profundas gargantas em quartzitos e drenagens em forma de baioneta. Ocorrem na estrada para o Parque Nacional das sempre Vivas, nas adjacências do Ribeirão do Inverno e Córrego Rapadura, bem como na borda leste da SdEM em geral, entre outros. 
c) Baixas Vertentes: representam áreas de contato entre os rebordos das chapadas e chapadões e os fundos de vales e terraços fluviais. Apresentam declividades mais elevadas, de 9 a 12 e e formam patamares escalonados.

\section{D) Áreas de Influência Imediata Fluvial}

a) Fundos de Vales e Terraços Quaternários: áreas geralmente hidromorfizadas, associadas à dinâmica dos rios e cursos d'água. Representam também as encostas que ligam o nível das chapadas e patamares às calhas fluviais e são mais representativas em rios que cortam outras litologias que não as quartzíticas do Supergrupo Espinhaço.

b) Planícies Aluviais: formadas por deposições fluviais, são mais representativas no médio curso do Rio Jequitinhonha, em trechos do alto Rio Pardo Pequeno, no Platô central, e também em trechos do Rio Paraúna, ao sul da Depressão de Gouveia, indicando o forte controle estrutural-litológico e morfológico sobre o escoamento e incisão da rede de drenagem na região mapeada.

\section{CONSIDERAÇÕES FINAIS}

Foram alcançados importantes resultados ao longo do processo de elaboração deste trabalho, os quais estão diretamente relacionados com as etapas metodológicas realizadas. Cabe ressaltar que entre os procedimentos metodológicos empregados para o mapeamento geomorfológicos, as técnicas de Geoprocessamento proporcionaram resultados satisfatórios, sobretudo no que se refere à delimitação das unidades geomorfológicas relacionadas na chave de interpretação proposta.

De um modo geral o presente trabalho buscou, através das técnicas de geoprocessamento otimizar o processo de produção do mapa geomorfológico da Serra do Espinhaço Meridional. Não foram alvos deste trabalho as discussões referentes à padronização de uma simbologia adequada ao mapeamento geomorfológico, as quais representam por se só uma linha de pesquisa a parte dentro da temática aqui abordada.

Utilizou-se cinco táxons, os dois primeiros com base na morfoestrutura e litologia do Espinhaço Meridional e do seu entorno mais imediato. Esses dois primeiros táxons foram escolhidos tendo em vista a importância dos fatores geológicos para a esculturação das formas de relevo do Espinhaço, e foram agrupados em: Domínio do Cráton do São Francisco, do Orógeno do Espinhaço, do Macaúbas e do Embasamento Cristalino. Estes, por sua vez foram subdivididos em litologias semelhantes.

Também foi levado em consideração dados moerfoesculturais, com a elaboração de mapas de classes de declividade, hipsométrico e de orientação do relevo, que permitiram a visualização de dois outros elementos da dinâmica do relevo e que constituiu a terceiro táxon: a das formas predominantemente erosivas e daquela predominantemente deposicionais. Estas, por sua vez, foram subdivididas em quatro outras (4o táxon), que originaram unidades, cujo detalhamento permitiu a identificação de dezenove subunidades de relevo, recorrentes em cada unidade.

O que se observa é que o Espinhaço (a SdEM) forma um maciço com grande variação de formas de relevo, no qual parte dos elementos de caráter estrutural vem sendo sobreposta pela atuação de processos de intemperismo e erosivos associados à atuação de climas mais úmidos. A esculturação do maciço vem sendo também realizada a partir das suas bordas, ou áreas de contato com outros domínios morfoestruturais.

Verificou-se, ainda, que a modelagem digital de elevação é um instrumento com grandes potencialidades para ser utilizado em análises geomorfológicas, bem como para representação cartográfica em geral das formas de relevo.

\section{AGRADECIMENTOS}

Ao Prof. Guilherme Knauer, do IGC-UFMG, profundo conhecedor do Espinhaço, pelas sugestões e discussões que muito contribuíram para esse mapeamento; ao Prof. Ricardo Diniz Costa, também do IGC, pelas contribuições ao longo da elaboração do texto. À FAPEMIG, pelo apoio financeiro ao Projeto que resultou neste mapeamento.

\section{BIBLIOGRAFIA}

Abreu A.A. de. 1982. Análise Geomorfológica: Reflexão e Aplicação - Uma contribuição ao conhecimento das formas de relevo do Planalto de Diamantina. USP. São Paulo, Tese de Doutorado, $429 \mathrm{p}$.

Almeida-Abreu P.A. 1995. O Supergrupo Espinhaço da Serra do Espinhaço Meridional (Minas Gerais): o Rifte, a Bacia e o Orógeno. Geonomos 3(1): 1-18.

Almeida Abreu P.A. \& Pflug R. 1994. The geodynamic evolution of the southern Serra do Espinhaço, Minas Gerais, Brazil . Zbl. Geol. Paläont., 1/2: 21-44.

Augustin C.H.R.R. \& Aranha P.R.A. 2006. A Ocorrência de Voçorocas em Gouveia, MG: características e processos associados. Geonomos 14 1(1, 2): 75-86,

Augustin C.H.R.R. \& Aranha P.R.A. 1999. Tropical landscape evolution: weathering and erosion processes in Gouveia, Minas Gerais, Brazil. In Regional Conference on Geomorphology - The Brazilian Geomorphological Union (UGB), Rio de Janeiro - RJ, p. 67.

Augustin C.H.R.R. 1995a. Geoökologische Studien im Südlichen Espinhaço Gebirge bei Gouveia, Minas Gerais, Brasilien Unter Besonderer Berucksichtigung der Landschaftsentwicklung. Universidade de Frankfurt, Frankfurt a.m., Alemanha. Tese de Doutorado, $254 \mathrm{p}$ 
Augustin C.H.R.R. 1995b. Aspectos Geomorfológicos da Região de Gouveia, Espinhaço Meridional, MG. In Anais ... $8^{\circ}$. Simpósio de Geologia de Minas Gerais. Diamantina, MG. Bol. SBG/MG, 1: 3-4.

Augustin C.H.R.R, Valadão R.C., Sanches H.M. 1994. Processos evolutivos da borda da Serra do Cabral (MG): evidências geomorfológicas e pedológicas. In Anais $38^{\circ}$ CONG. BRAS. GEOL., SBG, Camboriu-SC 3: 202-204.

Augustin C.H.R.R., Valadão R.C., Fogaça A.C.C. 1994. Gênese das coberturas superficiais vermelho-amarelas sobre o Grupo Macaúbas (Espinhaço Meridional /MG). In Anais $38^{\circ} \mathrm{CONG}$. BRAS. GEOL., SBG, Camboriu-SC, 3: 276-278.

Casseti V. 2005. Geomorfologia. [S.I.]: Disponível em: http://www.funape.org.br/geomorfologia/ Acesso em: 05/08/2011 (Cap. 2.2.1.1. - Características morfo-estruturais nas bacias sedimentares)

Cooke R.U. \& Doornkamp J.C. 1974. Geomorphology in Environmental Management. Clarenton Press, Oxford, 413p.

Costa R.D., Knauer L.G., Prezotti F.P.S., Duarte F.T., Fonseca H.A.M. 2011. Mapa Geológico da Folha Curvelo, SE.23-Z-A-V, 1:100.000. CPRM/UFMG

Demek J., Embleton C., Gellert J.F., Verstappen H.T. (Eds.) 1972. Manual of Detailed Geomorphological Mapping. Internationa Geographical Union Commission on Geomorphological Survay and Mapping. Academia, Prague. $344 \mathrm{p}$

Demeck J. 1967. Generalization of geomorphological maps. In: Proceedings of the meeting of the IGU-comission on applied geomorphology, sub-comission on geomorpholohy mapping. Progress made in geomorphological mapping. Breno and Bratislava, p. 36- 72.

Fogaça A.C.C. 1995. Geologia da Folha Diamantina. Projeto Espinhaço, COMIG/UFMG, 98 pp., Belo Horizonte.

Fonseca B. M. 2010. O uso do Sistema de Informações Geográficas na análise morfométrica e morfológica de bacias de drenagem na Serra do Espinhaço Meridional - MG. Instituto de Geociências, Universidade Federal de Minas Gerais. Dissertação (mestrado). 93p.

Goudie A., Anderson M., Burt T., Lewin J., Richards K., Whalley B., Worsley P. 1981. Geomorphological Techniques. In: British Geomorphological Research Group (Eds.), George Allen \& Unwin LTD, London. 395p.

Guerra A.T., Guerra A.J.T. 1997. Novo dicionário geológicogeomorfológico. Rio de Janeiro: Bertrand Brasil, 648p.

Gustavsson M., Kolstrup E., Seijmonsbergen, A. C. 2006 Geomorphology: a new symbol-and-GIS based detailed geomorphological mapping system: Renewal of a scientific discipline for understanding landscape development. Geomorphology 77: 90-111.

Hayden, R. S. 1986. Geomorphology From Space: A Global Overview of Regional Landforms, Chapter 11: Mapping". NASA. http://disc.sci.gsfc.nasa.gov/geomorphology/GEO_11/ index.shtml. Acesso em 01/10/2011.

IBGE. 1978. Mapa de Climas do Brasil. Rio de Janeiro, Escala 1:5.000.000

International Association of Geomorphologists (IAG). Geomorphological Group, APP GeoMAPPING, Home page acesso em 01/10/2011.

Instituto de Geografia e Estatística (IBGE). 1978. Mapa de Climas do Brasil. Rio de Janeiro, escala 1:5.000.000.

King L.C. 1956. Geomorfologia do Brasil Oriental. Rev. Bras.Geog., 18(2): $1147 p$
Knauer L.G., Ribeiro B.H., Freimann M., Ferreira M.P., Romano A.W. 2011. Geologia da Folha Corinto (SE.23-Z-A-II). CPRM/UFMG, 98 pp., Belo Horizonte-MG.

Knauer L.G. 2007. O Supergrupo Espinhaço em Minas Gerais: considerações sobre sua estratigrafia e seu arranjo estrutural. Geonomos 15(1): 81 - 90.

Knauer L.G., Grossi-Sad J. H. 1996. Geologia da Folha Serro (SE-23Z-B-IV). In: Grossi Sad, J. H., Lobato, L. M., Pedrosa-Soares, A. C. et al. (Eds.) Projeto Espinhaço.Belo Horizonte: COMIG, 1997. 1 CD-ROM.

Knauer L.G., Grossi-Sad J.H. 1996. Geologia da Folha Presidente Kubitschek. In: Grossi Sad J.H., Lobato L.M., Pedrosa-Soares, A. C. et al. (Eds.) Projeto Espinhaço.Belo Horizonte: COMIG, 1997. 1 CD-ROM.

Knauer L.G. 1990. Evolução geológica do Precambriano da porção centro leste da Serra do Espinhaço Meridional $e$ metalogênese associada. Dissertação de Mestrado, UNICAMP, 298p. Campinas.

Lane S.N, Richards K.S, Chandler J.H. 1998. Landform monitoring, modelling, and analysis. British Geomorphological Research Group Symposia Series. J. Wiley \& Sons Chichester, New York. $454 \mathrm{p}$.

Noce C.M., Fogaça A.C.C. 1997a. Geologia da Folha Curimataí. In: Grossi-Sad J.H., Lobato L.M., Pedrosa-Soares A.C., SoaresFilho B.S. (eds). Projeto Espinhaço em CD-Rom. Belo Horizonte, 1207-1250.

Oliveira F.V.C., Alkmim F.F. 1994. Estilo estrutural e curvatura da porção sul do front do Espinhaço. Anais ...CONG. BRAS. GEOL. 38, Cambouriu-SC

Pflug R. 1965. Die präkambrische Miogeosynklinale der Espinhaço- Kordilliere, Minas Gerais, Brasilien. - Geol. Rundschau, 56: $825-844$.

Ponçano W.L. 1981. Mapa geomorfológico do Estado de São Paulo, Volume 1. Instituto de Pesquisas Tecnológicas do Estado de São Paulo, Divisão de Minas e Geologia Aplicada.

Renger F. 1979. Evolução dos conceitos geológicos da Serra do Espinhaço. In: Anais ... Simp. Geol. Minas Gerais, Diamantina, SBG/MG. 1: 9-28.

Rodrigues S.C. 1998. Análise Empírico-Experimental da Fragilidade do Relevo-Solo no Cristalino do Planalto Paulistano: Sub-bacia do Reservatório Billings. FFLCH-USP, São Paulo, Tese de Doutorado. 267p.

Roque N.C, Noce C.M., Grossi-Sad J.H. Geologia da Folha Carbonita (SE-23-X-D-IV). In: Grossi Sad J.H., Lobato L.M., Pedrosa-Soares A.C. (Eds.) Projeto Espinhaço.Belo Horizonte: COMIG, 1997. 1 CD-ROM.

Ross J.L.S. 1992. O registro cartográfico dos fatos geomorfológicos e a questão da taxonomia do relevo. Depto de Geografia, USP 6: 17-29.

Ross J.L.S. 1997. Ensaios e experimentos na análise da fragilidade dos ambientes naturais: o penetrômetro de percussão. Revista do Departamento de Geografia, São Paulo, FFLCH/USP, 11: 57-66.

Ross J.L.S., Moroz I.C. 1997. Mapa geomorfológico do Estado de São Paulo : escala 1:500.000, Laboratório de Geomorfologia, Depto. Geografia, FFLCH-USP [e] Laboratório de Cartografia Geotécnica, Geologia Aplicada, IPT [e] FAPESP, Fundação de Amparo à Pesquisa do Estado de São Paulo.

Saadi A., Valadão R.C. 1987. Evolução geomorfológica quaternária da região de Gouveia, Serra do Espinhaço. In: SIMP. GEOL. MG 4, Belo Horizonte-MG, 1987. In: Anais SBG/MG,1987. Bol. SBG-MG, (7): 434-448. 
Saadi A. 1995. A Geomorfologia da Serra do Espinhaço em Minas Gerais e de suas margens. Geonomos, 3(1): 41-63.

Santos L.J.C., Oka-fiori C. Canali N.E., Fiori A.P., Silveira C.T., Silva J.M.F., Ross J.L.S. 2006. Mapeamento Geomorfológico do Estado do Paraná. Revista Brasileira de Geomorfologia , Ano 7, 2: 03-12.

Souza L.H.F., Ferreira I.L., Rodrigues S.C. 2003. Aplicação e desenvolvimento de simbologia gráfica empregada em mapeamento geomorfológico: um estudo de caso da abordagem cartográfica comparativa de metodologias geomorfológicas. In: Anais II SIMPÓSIO REGIONAL DE GEOGRAFIA "PERSPECTIVAS PARA O CERRADO NO SÉCULO XXI", Uberlândia, Brasil.

Tricart J. 1965. Principes et méthodes de geomorphologie. Paris: Masson Ed. 201p.
Tricart J., Cailleux A. 1965. Introduction a la géomorphologie climatique. Paris: SEDES. 419p.

Tupinambá M., Grossi-Sad J.H. 1997. Geologia da Folha Rio Vermelho. In: Grossi-Sad J.H., Lobato L.M., Pedrosa- Soares A.C., Soares-Filho B.S. (eds). Projeto Espinhaço em CD-Rom. Belo Horizonte, 1667-1806.

Twidale C.R. 2004. River patterns and their meaning. EarthScience Reviews 67 159-218. On line. Acesso: www.elsevier.com/locate/earscirev, em 8/10/2011.

Uhlein A. 1991. Transição cráton-faixa dobrada: exemplo do Cráton do São Francisco e da Faixa Araçuaí (Ciclo Brasiliano) no Estado de Minas Gerais: aspectos estratigráficos $e$ estruturais. USP, Tese de Doutorado. 295 p.

Verstappen H.Th. 1983. Applied Geomorphology: Geomorphological Surveys for Environmental Development. Elsevier, Amsterdam. 437p. 